\title{
Salicylic Acid Produced by Serratia marcescens 90-166 Is Not the Primary Determinant of Induced Systemic Resistance in Cucumber or Tobacco
}

\author{
C. M. Press, M. Wilson, S. Tuzun, and J. W. Kloepper \\ Department of Plant Pathology, Auburn University, AL 36849, U.S.A. \\ Received 12 September 1996. Accepted 5 May 1997.
}

\begin{abstract}
The rhizobacterial strain Serratia marcescens 90-166 mediates induced systemic resistance (ISR) to fungal, bacterial, and viral pathogens. It was determined that strain 90-166 produced salicylic acid (SA), using the salicylateresponsive reporter plasmid pUTK21. High-pressure liquid chromatography analysis of culture extracts confirmed the production of $\mathrm{SA}$ in broth culture. MiniTn5phoA mutants, which did not produce detectable amounts of SA, retained ISR activity in cucumber against the fungal pathogen Colletotrichum orbiculare. Strain 90166 induced disease resistance to Pseudomonas syringae pv. tabaci in wild-type Xanthi-nc and transgenic NahG-10 tobacco expressing salicylate hydroxylase. Increasing ferric iron concentrations in vitro reduced $\mathrm{SA}$ production below detectable limits, and increasing ferric iron concentration in planta, applied as a root drench, significantly reduced the level of ISR observed in cucumber to $C$. orbiculare. An ISR ${ }^{-}$mutant (90-166-2882) still produced SA. The results of this study indicate that SA produced by 90 166 is not the primary bacterial determinant of ISR and that this bacterial-mediated ISR system is affected by iron concentration.
\end{abstract}

Additional keyword: biocontrol.

The mechanisms by which rhizobacteria provide biological control of plant diseases have been a target of research for several years. In 1991, several researchers reported that specific rhizobacterial strains could induce disease resistance in cucumber (Wei et al. 1991), carnation (van Peer et al. 1991), and bean (Alström 1991). Induced systemic resistance (ISR) was defined by a working group at a NATO advanced research workshop on biological disease control (Kloepper et al. 1992) as active resistance dependent on the host plant's physical or chemical barriers, activated by biotic or abiotic agents (inducing agent). More recently, seed treatment of cucumber with rhizobacteria resulted in ISR against several pathogens of cucumber in greenhouse (Liu et al. 1995a, 1995b, 1995c; Raupach et al. 1996) and field experiments (Wei et al. 1996). Increases in plant lignification, phytoalexins, various lytic enzymes, and other pathogenesis-related (PR) proteins have been observed upon treatment of plants with different specific strains of rhizobacteria, providing presumptive evidence that

Corresponding author: C. M. Press; E-mail: cpress@acesag.auburn.edu
ISR may be involved in biocontrol provided by certain rhizobacteria (Albert and Anderson 1987; Frommel et al. 1991; Maurhofer et al. 1994; Sayler et al. 1994; van Peer et al. 1991; Zdor and Anderson 1992). The determinants by which rhizobacterial strains mediate ISR, however, are largely unknown.

Salicylic acid (2-hydroxybenzoic acid, SA) is one of several substances that, when applied exogenously, induce local and systemic defense responses in plants (White 1979; Yalpani et al. 1991). Ward et al. (1991) demonstrated increases in mRNA of several PR genes in SA-treated plants that were correlated with resistance to tobacco mosaic virus infection. Exogenously applied SA protected plant tissue against infection by numerous pathogens (Malamy et al. 1990; Çökmüş and Sayar 1991; Uknes et al. 1992). In addition, SA accumulated in cucumber in response to induction by pathogens and is thought to be transported through the phloem (Métraux et al. 1990). Gaffney et al. (1993) demonstrated that exogenously applied SA no longer induced transgenic tobacco plants producing salicylate hydroxylase (NahG), an enzyme that degrades SA. These studies have led to the suggestion of a role for SA in signaling of the defense response in plants (Métraux et al. 1990; Gaffney et al. 1993; Delaney et al. 1994; Shulaev et al. 1995).

Several genera of bacteria including pseudomonads are known to synthesize SA (Hudson and Bentley 1970; Ankenbauer and Cox 1988; Lebuhn and Hartmann 1994; Buysens et al. 1996) and SA is an intermediate in the biosynthesis of pyochelin siderophores (Ankenbauer and Cox 1988). SA is also an intermediate in the catabolism of naphthalene (Yen and Serdar 1988). There are some indications that SA may be involved in bacterially mediated ISR since Pseudomonas fluorescens strain $\mathrm{CHA} 0$, which provides ISR in tobacco to tobacco necrosis virus (Maurhofer et al. 1994), produces SA (Meyer et al. 1992; Visca et al. 1993). However, the role of SA production in CHA0-mediated ISR has not been reported. Leeman et al. (1996) reported that $P$. fluorescens strain WCS374, which provides ISR in radish to Fusarium oxysporum $\mathrm{f}$. sp. raphani, produced SA in quantities that were iron dose-dependent, and they suggested that ISR was due to bacterial SA production. Recently, De Meyer and Höfte (1997) reported the involvement of SA produced by Pseudomonas aeruginosa 7NSK2 in the induction of resistance against Botrytis cinerea on bean (Phaseolus vulgaris).

The purpose of this investigation was to determine if SA production by Serratia marcescens strain 90-166 was a determinant of ISR. This strain has been observed to induce sys- 
temic resistance to Colletotrichum orbiculare (Berk. \& Mont.) Arx (Liu et al. 1995c), Pseudomonas syringae pv. lachrymans (Liu et al. 1995b), F. oxysporum f. sp. cucumerinum (Liu et al. 1995a), cucumber mosaic virus (Raupach et al. 1996), and Erwinia tracheiphila (Yao et al. 1994) in numerous greenhouse trials, and to $P$. syringae pv. lachrymans (Wei et al. 1996), C. orbiculare (Wei et al. 1996), and E. tracheiphila (Yao et al. 1994) in field trials. Since SA is a precursor in the synthesis of pyochelin and SA has also been reported to function as a siderophore (Meyer et al. 1992), we hypothesized that SA production by $90-166$ would be iron $\left(\mathrm{Fe}^{+++}\right)$regulated and that loss of SA production would result in a reduction in ISR in cucumber. To test these hypotheses, we sought to (i) develop a bioassay for detection of bacterial-produced SA, (ii) evaluate the iron dose-dependent production of SA by $90-166$ in vitro and in planta and determine if 90-166-mediated ISR to anthracnose in cucumber was reduced at high iron levels, (iii) generate and screen mutants for loss of SA production $\left(\mathrm{SA}^{-}\right)$and test the ISR activity of these against anthracnose in cucumber, and (iv) test wild-type 90-166 and its $\mathrm{SA}^{-}$derivatives for ISR activity in tobacco Xanthi-nc and transgenic NahG-10 tobacco, which constitutively expresses salicylate hydroxylase (Gaffney et al. 1993).

\section{RESULTS}

In vitro $\mathrm{SA}$ screening assays.

A bioassay for bacterial production of SA was developed and used to screen the 90-166 mutant library. Cultures to be tested for SA production were grown on Luria-Bertani (LB) or King's medium B (KB) agar. If SA was produced, it diffused into the medium surrounding the test colony. When the indicator strain, $P$. fluorescens HK44(pUTK21), was oversprayed onto media containing SA and incubated, the strain bioluminesced. Bioluminescence was intensified by the addition of $n$ decyl aldehyde. Wild-type 90-166 produced a zone of inhibi- tion in the HK44(pUTK21) lawn; however, beyond this inhibition zone HK44(pUTK21) bioluminesced sufficiently strongly to be detected visually in a darkroom. The intensity of light production decreased as distance from the colony increased, resulting in an intense ring of light surrounding the colony that became progressively more diffuse farther away from the colony (Fig. 1). Control media or media inoculated with strains that did not produce SA did not result in visible levels of light production. The production of SA by wild-type 90-166 was quantified by high-pressure liquid chromatography (HPLC) at $2.89 \pm 0.95 \mu \mathrm{g} / \mathrm{ml}$ in stationary-phase cultures.

\section{Effect of iron on in vitro SA production.}

To evaluate the iron dose-dependent production of SA by 90166 in vitro, $\mathrm{KB}$ broth was amended with varying concentrations of iron $(1,10,50$, or $100 \mu \mathrm{M}$ or $3,30,140,270$, or 550 $\mu \mathrm{M})$ added as $\mathrm{FeCl}_{3}$ or Fe-EDTA, respectively. Since SA concentration was measured indirectly through bioluminescence of the reporter strain, it was expected that as iron availability increased, bioluminescence would decrease. As the iron concentration of the medium increased, the amount of bioluminescence produced by the reporter strain, HK44(pUTK21), decreased as expected (Fig. 2A and B), indicating that the amount of SA produced also decreased $\left(y=8.070 x^{2}-876.3 x+268,125.7, R^{2}=\right.$ 0.773 for strain 90-166 grown in $\mathrm{FeCl}_{3}$ amended medium or $y=$ $0.732 x^{2}-637.3 x+216,234.2, R^{2}=0.575$ for strain $90-166$ grown in Fe-EDTA amended medium). Both $\mathrm{FeCl}_{3}$ and $\mathrm{Fe}$ EDTA resulted in a reduction in the amount of SA produced when added at high concentrations. Control treatments indicated that bioluminescence by HK44(pUTK21) was not affected by $\mathrm{Fe}^{+++}$concentration at these levels.

Effects of SA and iron concentration on ISR in cucumber.

SA production and disease protection by $90-166$ were evaluated in planta at varying soil $\mathrm{Fe}^{+++}$concentrations. Total anthracnose lesion area increased as iron concentration increased
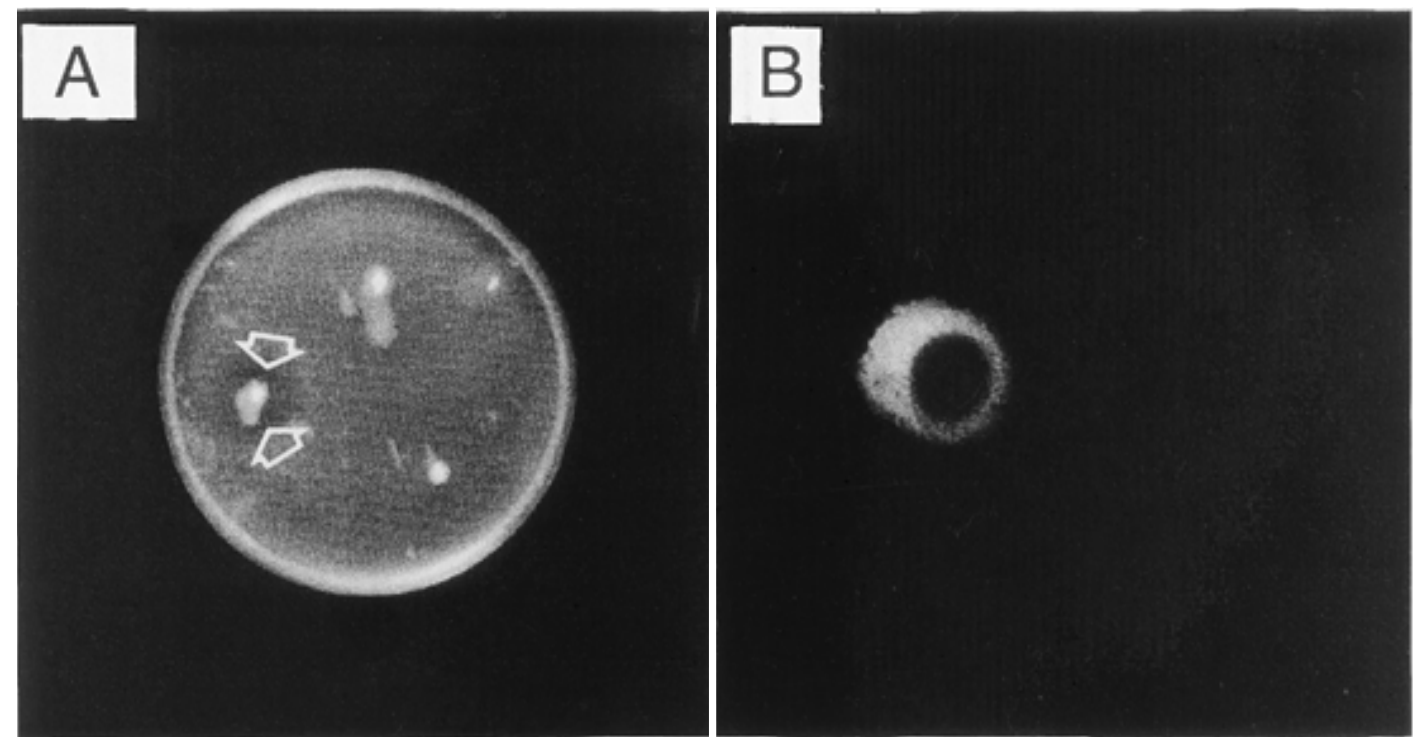

Fig. 1. A, Light photo showing colonies of wild-type 90-166 (left), and two SA ${ }^{-}$strains, 90-166-1441 (top right) and 90-166-2396 (bottom right). Colonies were grown for $48 \mathrm{~h}$, then plates were oversprayed with strain HK44(pUTK21) and incubated overnight. Zone of inhibition of HK44(pUTK21) (arrows) exists around wild-type 90-166. B, Dark photo showing identical plate as in A (to the same scale), but taken with a charge coupled device (CCD) camera. Bioluminescent halo surrounding wild-type 90-166 colony (left) indicative of SA production. 
$\left(y=-0.0018 x^{2}+0.0935 x+5.593, R^{2}=0.66\right)$ (Fig. 3). Cucumber plants were treated weekly with $0,1,3,6,12,22$, or $26 \mu \mathrm{M}$ Fe-EDTA-amended fertilizer. As the concentration of Fe-EDTA added to the pots was increased, the amount of protection provided by $90-166$ decreased. Strain 90-166 significantly reduced disease incidence compared with the control treatment $\mathrm{Fe}$ EDTA concentrations $(0 \mu \mathrm{M}, P=0.01 ; 6 \mu \mathrm{M}, P=0.007)$. No significant reductions in disease development were observed above $12 \mu \mathrm{M}$ Fe-EDTA. There was no effect of iron treatment on disease level in the nonbacterized control plants or in pathogen-induced plants. These results indicate that 90-166-mediated ISR was affected by iron concentration.

To determine if SA production was responsible for ISR by 90-166, mini-Tn5phoA mutants were screened for loss of SA production. With the SA bioassay described above, four mutants that no longer produced SA were identified (90-166$1441,-2396,-3624,-3850)$. HPLC analysis confirmed that these strains no longer produced detectable levels of SA (the detection limit was $187 \mathrm{ng}$ of SA per ml; Heitzer et al. 1992). These $\mathrm{SA}^{-}$mutants were inoculated onto cucumber seeds to determine if strains that had lost SA production still provided ISR in cucumber. All SA mutants retained ISR activity in cucumber at levels not significantly different from wild-type 90-166 (Table 1). To verify that cucumber could be induced by SA, SA was applied at varying concentrations as a root drench or by cotyledon infiltration. Significant $(P \leq 0.05)$ reductions in disease severity were observed in cucumber by drenching the root system with purified SA in the range of $100 \mathrm{pg}$ to 100 $\mu \mathrm{g}$ per root system. No induction of resistance was observed with SA concentrations below 100 pg per root system. Cucumbers were also induced by infiltration of cotyledons with SA concentrations of $1 \mathrm{ng}$ to $1 \mu \mathrm{g}$ per ml. A visible hypersensitive response was observed only in cotyledons infiltrated with $1 \mu \mathrm{g}$ of SA per ml. Levels of disease reduction were from 25 to $30 \%$ for both the cotyledon-injected and root-drench SA treatments. These levels are similar to the levels of disease reduction observed with the 90-166 treatment.

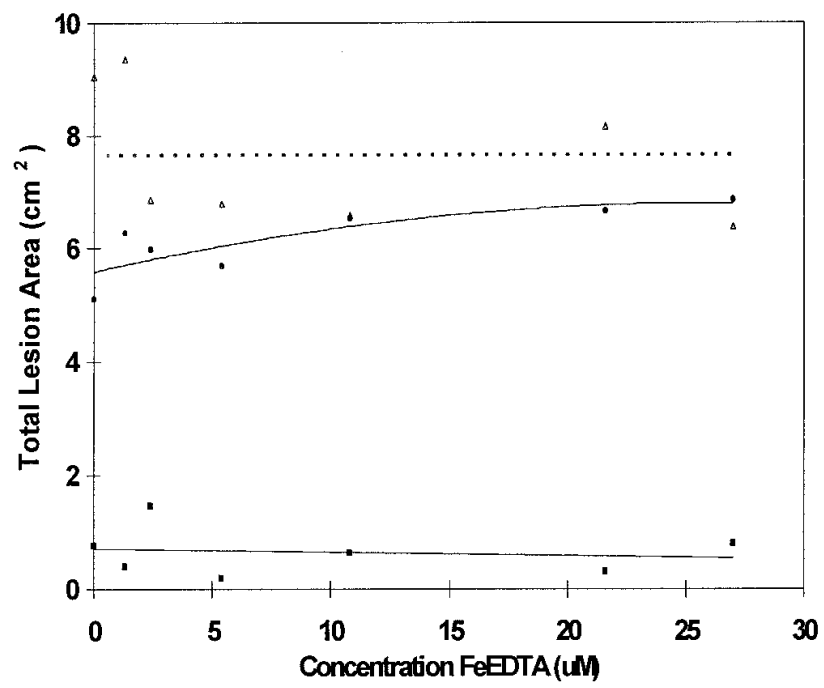

Fig. 3. Effect of increasing iron concentration in soil on induced systemic resistance (ISR) by strain 90-166. Iron was applied as diluted fertilizer solution (1.2 g/liter) amended with $0,1,3,6,12,22$, or $26 \mu \mathrm{M} \mathrm{Fe}-$ EDTA drench. Cucumber seeds were treated by soaking in saline (disease and pathogen-induced controls, $0.14 \mathrm{M} \mathrm{NaCl}$ ), or bacterial suspensions $(10 \log \mathrm{CFU} / \mathrm{ml})$. Colletotrichum orbiculare was applied by spraying plants to run-off with a $10^{5}$ conidia per ml suspension. The experiment was a $7 \times 3$ factorial (seven fertilizer levels and three treatments (nonbacterized, 90-166, or pathogen-induced) arranged in a randomized complete block design with eight replications. Disease was measured as total lesion area $\left(\mathrm{cm}^{2}\right) .\left(\bullet=90-166, R^{2}=0.664, y=\right.$ $-0.0018 x^{2}+0.0935 x+5.8929 ; \Delta=$ disease control; $\boldsymbol{\square}=$ pathogen induced control). Slope for the ISR control treatment was not significantly $(P \leq 0.05)$ different from zero. Slope for $90-166$ was significantly different from controls $(P \leq 0.05)$.
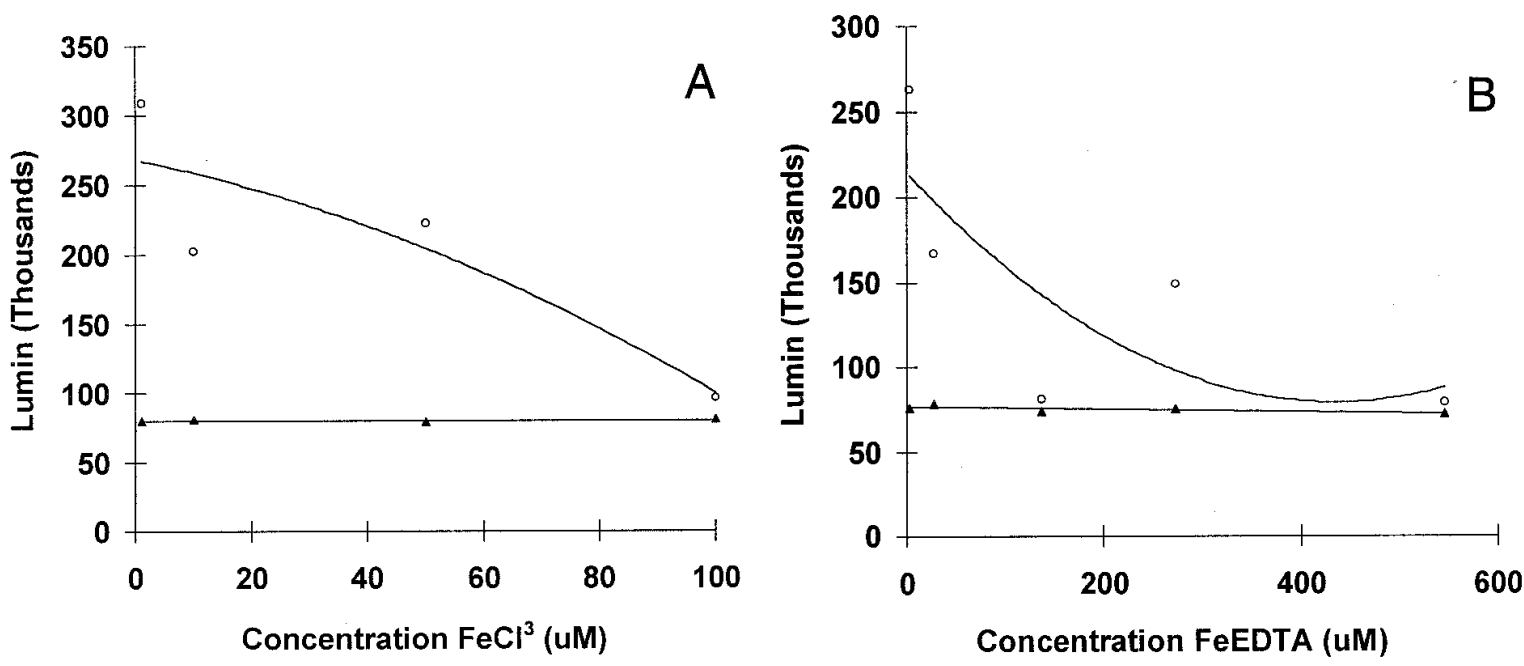

Fig. 2. Effect of increasing iron concentration of culture medium on salicylic acid (SA) production by $90-166$ in vitro. A, Iron was added to medium as $1,10,50$, or $100 \mu \mathrm{M} \mathrm{FeCl}_{3}$. SA production was measured indirectly by measuring bioluminescence of HK44(pUTK21). $y=8.070 x^{2}-876.3 x=$ $268,125.7, R^{2}=0.773$ for strain $90-166$. B, Iron was added to medium as $3,30,140,270$, or $550 \mu \mathrm{M}$ Fe-EDTA. $y=0.732 x^{2}-637.3 x+216,234.2, R^{2}=$ 0.575 for strain $90-166$. Slopes for control treatments were not significantly different from zero $(P \leq 0.05)$. Data are the mean of three replications and five subsamples. $(\bigcirc=90-166, \boldsymbol{\Delta}=$ control $)$ 


\section{ISR in NahG-10 tobacco.}

To further test whether bacterial-produced SA was involved in 90-166-mediated ISR, transgenic NahG-10 tobacco plants, which produce salicylate hydroxylase, were inoculated with 90166 or its $\mathrm{SA}^{-}$mutants. Both wild-type 90-166 and $\mathrm{SA}^{-}$mutants induced systemic disease resistance against $P$. syringae pv. $t a b$ aci (Tables 2 and 3) in both wild-type Xanthi-nc and NahG-10 tobacco, providing further evidence that bacterial SA production was not involved in 90-166-mediated ISR. Treatment of plants with SA $(1 \mu \mathrm{g} / \mathrm{ml})$ induced resistance in wild-type Xanthi-nc but not in NahG-10 plants, suggesting that the nahG construct was expressed in these plants and that the SA concentration produced by $90-166$ or its mutants was not high enough to saturate the salicylate hydroxylase enzyme. NahG-10 plants could be chemically-induced by 2,6-dichloroisonicotinic acid (INA) but not induced by $P$. syringae pv. tabaci.

\section{SA production by an $\mathrm{ISR}^{-}$mutant.}

Since SA did not appear to be the primary bacterial determinant of ISR, the mini-Tn5phoA mutant library was screened for mutations in other iron-related phenotypes. One mutant, 90-166-2882, no longer induced systemic resistance to C. orbiculare when inoculated onto cucumber plants. Disease severity of cucumbers treated with 90-166-2882 was not significantly different $(P=0.62)$ from the disease control, whereas pathogen-induced or wild-type 90-166-induced plants had significantly less disease ( $P=0.0001$ and 0.007 , respectively) than the disease control. Culture extracts of strain 90-1662882 contained SA $(1.86 \pm 0.63 \mu \mathrm{g} / \mathrm{ml})$ at levels that were not significantly different from those of the wild-type strain (2.89 $\pm 0.95 \mu \mathrm{g} / \mathrm{ml})(P=0.02)$, suggesting that bacterial production of SA is not involved in ISR by 90-166.

\section{DISCUSSION}

SA was not the sole bacterial determinant responsible for the induction of systemic resistance in cucumber and tobacco by $S$. marcescens strain $90-166$. $\mathrm{SA}^{-}$mutants retained induced resistance activity against $C$. orbiculare in cucumber at levels not significantly different from those of the $\mathrm{SA}^{+}$parental strain. Both the $\mathrm{SA}^{+}$parental strain and the $\mathrm{SA}^{-}$mutants in-

Table 1. Effect of salicylic acid (SA) production by Serratia marcescens strain 90-166 on induction of systemic resistance to Colletotrichum orbiculare in cucumber

\begin{tabular}{lc}
\hline Treatment $^{\mathbf{a}}$ & Mean severity $^{\mathbf{b}}$ \\
\hline Disease control & 0.955 \\
Pathogen-induced control & $0.444^{\mathrm{c}}$ \\
$90-166$ (wild-type, $\left.\mathrm{SA}^{+}\right)$ & $0.591^{\mathrm{c}}$ \\
$90-166-1441\left(\mathrm{SA}^{-}\right)$ & $0.618^{\mathrm{c}}$ \\
$90-166-2396\left(\mathrm{SA}^{-}\right)$ & $0.592^{\mathrm{c}}$ \\
$90-166-3624\left(\mathrm{SA}^{-}\right)$ & $0.623^{\mathrm{c}}$ \\
\hline
\end{tabular}

${ }^{a}$ Cucumber seeds were treated by soaking in saline (disease and pathogen-induced controls, $0.14 \mathrm{M} \mathrm{NaCl}$ ), or bacterial suspensions (10 log $\mathrm{CFU} / \mathrm{ml})$. C. orbiculare was applied by spraying plants to run-off with a $10^{5}$ conidia per $\mathrm{ml}$ suspension.

${ }^{b}$ Data are means of eight replications and were calculated by arcsine transformations of percent disease as determined with a disease rating scale (Thompson and Jenkins 1985). Data are from a representative experiment.

${ }^{c}$ Indicates a significant reduction in disease compared with the disease control at $P \leq 0.05$, using single-degree-of-freedom contrasts. duced resistance to $P$. syringae pv. tabaci in wild-type Xanthinc tobacco and transgenic NahG-10 tobacco expressing salicylate hydroxylase. However, it is still possible that SA is responsible for induction of resistance by other rhizobacteria or in other hosts. Leeman et al. (1996) concluded that SA was responsible for induction of resistance in radish to $F$. oxysporum f. sp. raphani by $P$. fluorescens strain WCS374. In the radish system, disease control decreased as soil iron concentration increased, suggesting that a corresponding in planta decrease in SA was responsible for loss of protection with WCS374 at higher iron levels. Further, De Meyer and Höfte (1997) concluded that SA was involved in ISR in bean against $B$. cinerea induced by $P$. aeruginosa.

Our results are consistent with the results of Leeman et al. (1996) and De Meyer and Höfte (1997) that rhizobacterialmediated ISR is affected by iron concentration. Disease control by $90-166$ decreased in cucumber as the iron concentration supplied in the fertilizer solution increased, while increased iron concentration in the absence of inducing bacteria had no effect on the level of disease. Leeman et al. (1996) suggested that, since SA is a precursor in pyochelin synthesis, its production should be stimulated by low iron concentrations. We have not observed that strain 90-166 produces any siderophores in the

Table 2. Induction of systemic resistance in wild-type Xanthi-nc and NahG-10 tobacco to Pseudomonas syringae pv. tabaci by 90-166

\begin{tabular}{lcc}
\hline & \multicolumn{2}{c}{ Mean severity $^{\mathbf{b}}$} \\
\cline { 2 - 3 } Treatment $^{\mathrm{a}}$ & Xanthi-nc WT $^{\text {NahG-10 }}$ \\
\hline Disease control & 0.179 & 0.417 \\
INA & $0.080^{\mathrm{c}}$ & $0.221^{\mathrm{c}}$ \\
$90-166$ & $0.094^{\mathrm{c}}$ & $0.156^{\mathrm{c}}$ \\
\hline
\end{tabular}

${ }^{\text {a }}$ Six-week-old tobacco seedlings were treated by stem injection of 200 $\mu \mathrm{l}$ of saline $(0.14 \mathrm{M} \mathrm{NaCl}$, disease control), or 2,6-dichloro-isonicotinic acid (INA, $0.35 \mathrm{M}$ ), or 90-166 bacterial suspension (10 log CFU/ $\mathrm{ml})$.

${ }^{\mathrm{b}}$ Data are means of six replications and were calculated by arcsine transformations of percent disease as determined with a 0 to 5 disease rating scale in which $0=$ no disease and $5=$ a totally necrotic leaf. Data are from a representative experiment.

${ }^{c}$ Treatments were significantly lower than the water control based on single-degree-of-freedom contrasts $(P \leq 0.05)$.

Table 3. The effect of bacterial production of salicylic acid (SA) on induced systemic resistance in transgenic NahG-10 tobacco to Pseudomonas syringae pv. tabaci

\begin{tabular}{lc}
\hline Treatment $^{\mathbf{a}}$ & Mean severity $^{\mathbf{b}}$ \\
\hline Disease control & 0.324 \\
INA & $0.203^{\mathrm{c}}$ \\
SA & 0.316 \\
$90-166$ & $0.230^{\mathrm{c}}$ \\
$1441\left(\mathrm{SA}^{-}\right)$ & $0.223^{\mathrm{c}}$ \\
$2396\left(\mathrm{SA}^{-}\right)$ & $0.183^{\mathrm{c}}$ \\
$3624\left(\mathrm{SA}^{-}\right)$ & $0.238^{\mathrm{c}}$ \\
\hline
\end{tabular}

${ }^{a}$ Six-week-old tobacco seedlings were treated by stem injection of 200 $\mu \mathrm{l}$ of saline $(0.14 \mathrm{M} \mathrm{NaCl}$, disease control), or 2,6-dichloro-isonicotinic acid (INA, $0.35 \mathrm{M})$, or SA $(0.1 \mathrm{mM})$, or bacterial suspensions (10 $\log \mathrm{CFU} / \mathrm{ml})$.

${ }^{\mathrm{b}}$ Data are means of six replications and were calculated by arcsine transformations of percent disease as determined with a 0 to 5 disease rating scale in which $0=$ no disease and $5=$ a totally necrotic leaf. Data are from a representative experiment.

${ }^{c}$ Treatments were significantly lower than the water control based on single-degree-of-freedom contrasts $(P \leq 0.05)$. 
hydroxymate class such as pyochelin; however, Meyer et al. (1992) reported that SA itself can function as an endogenous siderophore, suggesting that SA production may be promoted by low iron concentrations. With strain 90-166, SA concentrations in broth cultures decreased as the concentration of supplemental iron in the medium increased. However, because $\mathrm{SA}^{-}$strains retained induced resistance activity on cucumber and transgenic NahG-10 tobacco, we conclude that ISR by these strains was affected by iron concentration but was not primarily due to the production of SA.

While it is possible that $\mathrm{SA}^{-}$mutants produced SA that was below the HPLC detection limit of $187 \mathrm{ng} / \mathrm{ml}$, the ISR $^{-}$mutant that no longer induced resistance in cucumber produced SA at concentrations not significantly different from those of the wild-type strain. Furthermore, results with transgenic tobacco support the conclusion that microbial SA production by 90 166 was not involved in induced resistance, since this strain was able to induce NahG-10 tobacco, which expresses salicylate hydroxylase.

It is possible that the $\mathrm{SA}^{-}$mutants compensated for loss of SA production by overproduction of an SA precursor or production of another compound and that one of these compounds may have induced resistance in cucumber or transgenic NahG-10 tobacco. The SA biosynthetic pathway in 90-166 is unknown; however, the most common pathway for salicylate biosynthesis in bacteria is through chorismate and isochorismate (Marshall and Ratledge 1972; Serino et al. 1995). It is not known if SA biosynthesis proceeds through either of these compounds in 90-166 or if they are accumulated in the $\mathrm{SA}^{-}$mutants. Induction of resistance in cucumber with chorismate or isochorismate has not been reported, but it is unlikely that accumulation of these precursors would occur, since they are involved in other pathways of bacterial metabolism including synthesis of enterobactin, a commonly occurring catechol siderophore in Enterobacteriaceae. Results with an $\mathrm{SA}^{+}$and $\mathrm{ISR}^{-}$mutant support the conclusion that bacterial SA production was not a primary determinant involved in induction of host resistance in this system.

While SA production in 90-166 was suppressed at high iron concentrations, these data suggest that SA was not the primary determinant of ISR in this system and that the effect of iron

Table 4. Bacterial strains used in this study

\begin{tabular}{|c|c|c|}
\hline Strain & Description & Source \\
\hline $90-166$ & $\begin{array}{l}\text { Serratia marcescens, } \mathrm{Tc}^{\mathrm{r}} \\
\quad \text { (intrinsic) }\end{array}$ & J. W. Kloepper \\
\hline 90-166-1441 & $\begin{array}{l}\text { S. marcescens, } \mathrm{Tc}^{\mathrm{r}} \text {, mini-Tn } 5 \\
\text { phoA, } \mathrm{Km}^{\mathrm{r}}, \mathrm{SA}^{-}\end{array}$ & This study \\
\hline 90-166-2396 & $\begin{array}{l}\text { S. marcescens, } \mathrm{Tc}^{\mathrm{r}} \text {, mini-Tn } 5 \\
\quad \text { phoA, } \mathrm{Km}^{\mathrm{r}}, \mathrm{SA}^{-}\end{array}$ & This study \\
\hline $90-166-3624$ & $\begin{array}{l}\text { S. marcescens, } \mathrm{Tc}^{\mathrm{r}} \text {, mini-Tn } 5 \\
\text { phoA, } \mathrm{Km}^{\mathrm{r}}, \mathrm{SA}^{-}\end{array}$ & This study \\
\hline $90-166-2882$ & $\begin{array}{l}\text { S. marcescens, } \mathrm{Tc}^{\mathrm{r}} \text {, mini-Tn5 } \\
\quad \text { phoA }, \mathrm{Km}^{\mathrm{r}}, \mathrm{Sid}^{-}\end{array}$ & This study \\
\hline HK44 & $\begin{array}{l}\text { Pseudomonas fluorescens, } \\
\text { pUTK21::nahG-luxCDABE } \\
\mathrm{Tc}^{\mathrm{r} \text { a }}\end{array}$ & G. Sayler \\
\hline SM10 & $\begin{array}{l}\text { Escherichia coli, pUT mini- } \\
\text { Tn } 5 p h o A, \mathrm{Km}^{\mathrm{r}}\end{array}$ & $\begin{array}{l}\text { K Timmis; de Loren- } \\
\text { zo et al. (1990) }\end{array}$ \\
\hline $89 \mathrm{C}-14$ & $\begin{array}{l}\text { Pseudomonas syringae pv. } \\
\text { tabaci }\end{array}$ & J. W. Kloepper \\
\hline
\end{tabular}

$\bar{a}$ nahG = salicylate hydroxylase gene from Pseudomonas putida strain 5R (pNAH7) (King et al. 1990). was mediated through some other means. High iron levels in the rhizosphere may have suppressed production of a siderophore or some other iron-regulated compound produced by 90-166 that was directly or indirectly involved in ISR. Leeman et al. (1996) reported that a purified siderophore, pseudobactin, from strain WCS374 induced resistance to $F$. oxysporum f. sp. raphani in radish. However, a pseudobactindeficient strain, 374PSB ${ }^{-}$, retained induced resistance activity, suggesting that siderophore production by this strain was only partially responsible for induction of systemic resistance in radish. Further, Maurhofer et al. (1994) reported that a pyoverdine-deficient derivative of strain $\mathrm{CHAO}$ no longer induced disease resistance to tobacco necrosis virus in tobacco. However, siderophore-mediated ISR is apparently siderophore-specific since Leeman et al. (1996) reported that a purified siderophore from strain WCS358 did not induce resistance. Both wild-type 90-166 and $\mathrm{SA}^{-}$mutants produced siderophores on chrome azurol S (CAS) medium and the ISR ${ }^{-}$ $\mathrm{SA}^{+}$strain 90-166-2882, which was also $\mathrm{Sid}^{-}$, no longer induced resistance against $C$. orbiculare at levels significantly different from the disease control $(P=0.62)$, supporting a role for low iron concentrations in ISR mediated by $90-166$. However, further analysis is necessary to confirm the involvement of the siderophore(s) produced by $90-166$ in induced resistance and to evaluate the $\mathrm{Sid}^{-}$mutant for pleiotropic effects of the mutation.

\section{MATERIALS AND METHODS}

\section{Mutagenesis.}

The plasmid vector pUT containing mini-Tn5phoA was used to perform transposon mutagenesis on strain 90-166 to obtain SA-deficient $\left(\mathrm{SA}^{-}\right)$strains to determine the contribution of this phenotype to the wild-type strain's ability to induce systemic resistance. For biparental matings, 90-166 and SM10 (Table 4; de Lorenzo et al. 1990) were inoculated into LB broth or LB amended with $50 \mu \mathrm{g}$ of kanamycin per ml, respectively, and grown overnight to obtain log-phase cultures. Donor and recipient strains were mixed in a ratio of 10:1 and spotted onto nitrocellulose filters placed on LB agar plates. Strains were incubated for $4 \mathrm{~h}$ at $28^{\circ} \mathrm{C}$, and then filters were transferred to $\mathrm{LB}$ agar containing $50 \mu \mathrm{g}$ of kanamycin and $100 \mu \mathrm{g}$ of tetracycline $\left(\mathrm{LB}^{\mathrm{KanTet}}\right)$ per $\mathrm{ml}$ and incubated for 36 to $48 \mathrm{~h}$. Colonies were then transferred to fresh $\mathrm{LB}^{\mathrm{KanTet}}$, streaked for single colonies, transferred to 96-well microtiter plates containing LB amended with $20 \%$ glycerol, and stored at $-80^{\circ} \mathrm{C}$.

\section{In vitro SA screening assays.}

The following assay system was utilized to rapidly identify strains that produced SA and to identify mutant strains that no longer produced SA. To screen for $\mathrm{SA}^{-}$mutants, bacteria were spotted on LB agar and grown for $48 \mathrm{~h}$ at $28^{\circ} \mathrm{C}$. P. fluorescens strain HK44(pUTK21) (Table 4; Heitzer et al. 1992) was grown in minimal medium Davis (MMD; Difco, Detroit, MI) amended with $10 \mathrm{~g}$ of sucrose per liter for $18 \mathrm{~h}$. To visualize SA production, HK44(pUTK21) broth was diluted 100-fold in phosphate buffer $(0.02 \mathrm{M})$ to $\log 8.0 \mathrm{CFU} / \mathrm{ml}$ and oversprayed onto $\mathrm{LB}$ agar plates with colonies of $90-166$ or mini-Tn5phoA mutants as described above. Plates were incubated at $25^{\circ} \mathrm{C}$ for $24 \mathrm{~h}$. Immediately before visualization, $10 \mu \mathrm{l}$ of n-decyl aldehyde (Sigma, St. Louis, MO) was spotted on the lid of each plate, and biolu- 
minescence was observed in the dark. Strains producing SA were evident by a bright halo surrounding the colony. With this assay, mutants were screened for loss of SA production as evidenced by loss of the halo surrounding the colonies (Fig. 1). Culture extracts from these strains were analyzed for SA by HPLC (see below) to verify the loss of SA production in $\mathrm{SA}^{-}$ mutants. The plasmid, pUTK21, can detect SA at a lower limit of approximately $187 \mathrm{ng} / \mathrm{ml}$ (Heitzer et al. 1992).

\section{Extraction and quantification of SA.}

To verify SA production in wild-type cultures, SA was extracted from 48-h stationary-phase cultures grown in $\mathrm{KB}$ broth. Cultures were centrifuged, and supernatant was acidified with $\mathrm{HCl}$ to $\mathrm{pH} 2.0$ and extracted with $2 \mathrm{ml}$ of chloroform (Meyer et al. 1992). Ten-microliter samples were injected into a Nova-Pak C-18 column $(3.9 \times 150 \mathrm{~mm})$ (Waters, Milford, MA). SA was separated isocratically with $20 \%$ (vol/vol) methanol in $20 \mathrm{mM}$ sodium acetate buffer $(\mathrm{pH} 5.0)$ with a flow rate of $1.0 \mathrm{ml} / \mathrm{min}$. SA was quantified with a fluorescence detector set at 313 and $405 \mathrm{~nm}$ (excitation and emission, respectively). HPLC analysis was performed with three replications and three subsamples per treatment. The detection limit was $15.2 \mathrm{ng}$ of SA per ml based on an extraction efficiency of $12 \%$ from KB broth to which a known quantity of SA was added.

\section{Siderophore production.}

Production of siderophores by either 90-166 or miniTn5phoA mutants was measured on CAS medium (Schwyn and Neilands 1987). Bacteria were spotted onto plates, incubated at $28^{\circ} \mathrm{C}$ for $24 \mathrm{~h}$, and observed for production of an orange halo surrounding the colonies indicative of siderophore production. Mini-Tn5phoA mutants were also screened on CAS medium for loss of siderophore production (absence of orange halo). Strain 90-166-2882 was selected, which no longer produced a siderophore on CAS.

\section{Effect of iron on in vitro SA production.}

The effect of increasing iron concentration on the bacterial production of SA was measured in vitro. Strain 90-166 was grown in $10 \mathrm{ml}$ of $\mathrm{KB}$ broth amended with $1,10,50$, or 100 $\mu \mathrm{M} \mathrm{FeCl}{ }_{3}$ or $3,30,140,270$, or $550 \mu \mathrm{M}$ Fe-EDTA for $48 \mathrm{~h}$ at $25^{\circ} \mathrm{C}$ with shaking $(150 \mathrm{rpm}$; Digital Oscillator, Barnstead Thermolyne, Dubuque, IA). Broth was centrifuged, and supernatant was filtered through a $0.2-\mu \mathrm{m}$ nitrocellulose filter to remove remaining bacterial cells. Three milliliters of filtrate was added to $10 \mathrm{ml}$ of fresh $\mathrm{KB}$; this was inoculated with HK44(pUTK21) and incubated for $18 \mathrm{~h}$ at $25^{\circ} \mathrm{C}$ and $150 \mathrm{rpm}$ (Digital Oscillator, Barnstead Thermolyne). After incubation, 1-ml samples were removed, $10 \mu \mathrm{l}$ of n-decyl aldehyde was added, samples were vortexed, and bioluminescence was measured in a luminometer (Analytical Luminescence Lab., San Diego, CA) with 10-s integrations. Control treatments included HK44(pUTK21) alone grown at varying iron levels in $\mathrm{KB}$ (negative controls) and HK44(pUTK21) grown in KB amended with $0.05 \%$ SA (positive control). All treatment combinations had three replications and five subsamples. Analysis of variance was performed and treatment means were compared by single degree-of-freedom contrasts. Data were regressed and plotted to determine the relationship between SA production and iron concentration.
Effects of SA and iron concentration on ISR in cucumber.

Experiments were conducted with $\mathrm{SA}^{-}$strains to determine if bacterial SA production was involved in ISR in cucumber or tobacco. Strain $90-166$ or $\mathrm{SA}^{-}$mutants were grown in $\mathrm{LB}$ or $\mathrm{LB}^{\mathrm{KanTet}}$, respectively, for $24 \mathrm{~h}$ at $25^{\circ} \mathrm{C}$ with shaking at 200 rpm (Digital Oscillator, Barnstead Thermolyne). Strains were centrifuged and resuspended in physiological saline $(0.14 \mathrm{M}$ $\mathrm{NaCl}$ ). Cucumber seeds (Cucumis sativus cv. SMR58) were soaked in bacterial suspensions for $30 \mathrm{~min}$ and then planted in pots containing potting mix (Promix, Premier Peat, Rivièredu-Loup, Quebec). Seeds were covered, and pots were placed on a greenhouse bench for the duration of the experiment. Plants were fertilized with 15-16-17 (2.5 g/liter) at 14 days after planting and were challenged with the pathogen, $C$. orbiculare, at 28 days after planting. The pathogen was applied by spraying plants to run-off with a $10^{5}$ conidia/ml suspension. Plants were placed in a humid chamber for $24 \mathrm{~h}$ and then returned to the greenhouse bench. Pots were arranged in a randomized complete block design with eight replications. For these experiments, total lesion area was measured initially with a leaf area meter (Agvision, Decagon Devices, Pullman, WA) and area measurements were converted to percent diseased leaf area. These percentages were then used to place disease ratings into eight categories to recreate the disease rating scale of Thompson and Jenkins (1985) according to this model system. Each leaf was rated per plant on a disease rating scale in which $1=0$ to $1 \%, 2=1$ to $3 \%, 3=3$ to $6 \%, 4=$ 6 to $12 \%, 5=12$ to $25 \%, 6=25$ to $50 \%, 7=50$ to $75 \%$, and 8 $=75$ to $100 \%$ leaf area infected (Thompson and Jenkins 1985); these rates were averaged and converted back to percentages to obtain plant disease severity measurements per plant. Control treatments included nonbacterized (disease) control and a pathogen-induced (positive) control. Significant treatment differences were determined after arcsine transformation and compared by single-degree-of-freedom contrasts. Experiments to test the ISR ${ }^{-}$mutant were performed as for the $\mathrm{SA}^{-}$mutants with the strain 90-166-2882.

Experiments were designed to determine if increasing iron concentrations in planta reduced disease resistance induced by 90-166. Cucumber plants were fertilized weekly with diluted fertilizer solution (1.2 g/liter) amended with $0,1,3,6,12,22$, or $26 \mu \mathrm{M}$ Fe-EDTA. The experiment was a $7 \times 3$ factorial (seven fertilizer levels and three treatments (nonbacterized, 90-166, or pathogen-induced) arranged in a randomized complete block design with eight replications. Disease was measured as total lesion area $\left(\mathrm{cm}^{2}\right)$ and disease ratings were not performed for these experiments. All other aspects of the experiment were as described above.

\section{ISR in tobacco.}

Wild-type tobacco (Nicotiana tabacum cv. Xanthi-nc) and transgenic tobacco (Xanthi-nc line NahG-10) were provided by J. Ryals (Ciba-Geigy Agricultural Biotechnology, Research Triangle Park, NC). NahG-10 tobacco contains the nahG coding sequence (for salicylate hydroxylase) under the control of a $35 \mathrm{~S}$ cauliflower mosaic virus (CaMV) promoter (Gaffney et al. 1996). Experiments were designed to determine the involvement of SA production by 90-166 in the induction of disease resistance by testing the potential of 90-166 and the $\mathrm{SA}^{-}$mutants to induce tobacco plants expressing salicylate hydroxylase. Plants were inoculated with $90-166$ or the $\mathrm{SA}^{-}$ 
mutants by stem injection of $0.2 \mathrm{ml}$ of bacterial suspension (10 log CFU/ml) into stems of 6-week-old tobacco plants. Bacteria were grown in $100 \mathrm{ml}$ of $\mathrm{KB}$ (for wild-type) or $\mathrm{KB}^{\text {KanTet }}$ (for mutants) for $24 \mathrm{~h}$ at $25^{\circ} \mathrm{C}$ with shaking (200 rpm; Digital Oscillator, Barnstead Thermolyne) to yield approximately $10.5 \log \mathrm{CFU} / \mathrm{ml}$. Cultures were centrifuged and resuspended in an equal volume of saline (as mentioned previously). Control plants were saline-injected (disease control), pathogen-induced, SA $(0.1 \mathrm{mM})$ or INA-induced $(0.35 \mathrm{M}$; Novartis, Greensboro, NC). The pathogen, P. syringae pv. tabaci, was grown in $100 \mathrm{ml}$ of $\mathrm{KB}$ for $24 \mathrm{~h}$ at $25^{\circ} \mathrm{C}$ with shaking (200 rpm; Digital Oscillator, Barnstead Thermolyne) and then diluted 100-fold (to a final concentration of $8 \mathrm{log}$ $\mathrm{CFU} / \mathrm{ml}$ ) in $0.02 \mathrm{M}$ phosphate buffer ( $\mathrm{pH} \mathrm{6.8)} \mathrm{amended} \mathrm{with}$ $0.2 \%$ (vol/vol) Silwet L-77 (Union Carbide, Tarrytown, NY). Ten days after induction, plants were sprayed to run-off with the pathogen, placed in a humid chamber for $24 \mathrm{~h}$, and then returned to the greenhouse. Pots were arranged in a randomized complete block design with six replications. Disease was rated per leaf on a 0 to 5 disease rating scale in which $0=$ no lesions and $5=75$ to $100 \%$ of leaf covered with lesions. Data were analyzed as described above.

\section{ACKNOWLEDGMENTS}

We wish to thank R. Shelby and D. Zhang for technical advice on HPLC and R. Rodriguez-Kabana for advice on the chemistry of SA and siderophores.

\section{LITERATURE CITED}

Albert, F., and Anderson, A. J. 1987. The effect of Pseudomonas putida colonization on root surface peroxidase. Plant Physiol. 85:537-541.

Alström, S. 1991. Induction of disease resistance in common bean susceptible to halo blight bacterial pathogen after seed bacterization with rhizosphere pseudomonads. J. Gen. Appl. Microbiol. 37:495-501.

Ankenbauer, R. G., and Cox, C. D. 1988. Isolation and characterization of Pseudomonas aeruginosa mutants requiring salicylic acid for pyochelin biosynthesis. J. Bacteriol. 170:5364-5367.

Buysens, S., Heungens, K., Poppe, J., and Höfte, M. 1996. Involvement of pyochelin and pyoverdin in suppression of Pythium-induced damping-off of tomato by Pseudomonas aeruginosa 7NSK2. Appl. Environ. Microbiol. 62:865-871.

Çökmüş, C., and Sayar, A. H. 1991. Effect of salicylic acid on the control of bacterial speck of tomato caused by Pseudomonas syringae pv. tomato. J. Turk. Phytopathol. 20:27-32.

de Lorenzo, V., Herrero, M., Jakubzik, U., and Timmis, K. N. 1990. Mini-Tn5 transposon derivatives for insertion mutagenesis, promoter probing, and chromosomal insertion of cloned DNA in Gram-negative eubacteria. J. Bacteriol. 172:6568-6572.

De Meyer, G., and Höfte, M. 1997. Salicylic acid produced by the rhizobacterium Pseudomonas aeruginosa 7NSK2 induces resistance to leaf infection by Botrytis cinerea on bean. Phytopathology 87:588-593.

Delaney, T. P., Uknes, S., Vernooij, B., Friedrich, L., Weymann, K., Negrotto, D., Gaffney, T., Gut-Rella, M., Kessmann, H., Ward, E., and Ryals, J. 1994. A central role of salicylic acid in plant disease resistance. Science 266:1247-1250.

Frommel, M. I., Nowak, J., and Lazarovits, G. 1991. Growth enhancement and developmental modifications of in vitro grown potato (Solanum tuberosum ssp. tuberosum) as affected by a nonfluorescent Pseudomonas sp. Plant Physiol. 96:928-936.

Gaffney, T., Friedrich, L., Vernooij, B., Negrotto, D., Nye, G., Uknes, S., Ward, E., Kessmann, H., and Ryals, J. 1993. Requirement of salicylic acid for the induction of systemic acquired resistance. Science 261:754-756

Heitzer, A., Webb, O. R., Thonnard, J. E., and Sayler, G. S. 1992. Specific and quantitative assessment of naphthalene and salicylate bioavailability by using a bioluminescent catabolic reporter bacte- rium. Appl. Environ. Microbiol. 58:1839-1846.

Hudson, A. T., and Bentley, R. 1970. Utilization of shikimic acid for the formation of mycobactin $\mathrm{S}$ and salicylic acid by Mycobacterium smegmatis. Biochemistry 9:3984-3987.

King, J. M. H., DiGrazia, P. M., Applegate, B., Burlage, R., Sanseverino, J., Dunbar, P., Larimer, F., and Sayler, G. S. 1990. Rapid, sensitive bioluminescent reporter technology for naphthalene exposure and biodegradation. Science 249:778-781.

Kloepper, J. W., Tuzun, S., and Kuc, J. A. 1992. Proposed definitions related to induced disease resistance. Biocontrol Sci. Technol. 2:349351 .

Lebuhn, M., and Hartmann, A. 1994. Production of auxin and Ltryptophan related indolic and phenolic compounds by Azospirillum brasilense and Azospirillum lipoferum. Pages 145-147 in: Improving Plant Productivity with Rhizosphere Bacteria. M. H. Ryder, P. M. Stephens, and G. D. Bowen, eds. CSIRO, Glen Osmond, Australia.

Leeman, M., den Ouden, F. M., van Pelt, J. A., Dirkx, F. P. M., Steij1, H., Bakker, P. A. H. M., and Schippers, B. 1996. Iron availability affects induction of systemic resistance to Fusarium wilt of radish by $\mathrm{Pseu}$ domonas fluorescens. Phytopathology 86:149-155.

Liu, L., Kloepper, J. W., and Tuzun, S. 1995a. Induction of systemic resistance in cucumber against Fusarium wilt by plant growthpromoting rhizobacteria. Phytopathology 85:695-698.

Liu, L., Kloepper, J. W., and Tuzun, S. 1995b. Induction of systemic resistance in cucumber against bacterial angular leaf spot by plant growth-promoting rhizobacteria. Phytopathology 85:843-847.

Liu, L., Kloepper, J. W., and Tuzun, S. 1995c. Induction of systemic resistance in cucumber by plant growth-promoting rhizobacteria: Duration of protection and effect of host resistance on protection and root colonization. Phytopathology 85:1064-1068.

Malamy, J., Carr, J. P., Klessig, D. F., and Raskin, I. 1990. Salicylic acid: A likely endogenous signal in the resistance response of tobacco to viral infection. Science 250:1002-1004.

Marshall, B. J., and Ratledge, C. 1972. Salicylic acid biosynthesis and its control in Mycobacterium smegmatis. Biochim. Biophys. Acta. 264:106-116

Maurhofer, M., Hase, C., Meuwly, P., Métraux, J. -P., and Défago, G. 1994. Induction of systemic resistance of tobacco to tobacco necrosis virus by the root-colonizing Pseudomonas fluorescens strain CHA0: Influence of the gacA gene and of pyoverdine production. Phytopathology 84:139-146.

Métraux, J. P., Signer, H., Ryals, J., Ward, E., Wyss-Benz, M., Gaudin, J., Raschdorf, K., Schmid, E., Blum, W., and Inverardi, B. 1990. Increase in salicylic acid at the onset of systemic acquired resistance in cucumber. Science 250:1004-1006.

Meyer, J-M., Azelvandre, P., and Georges, C. 1992. Iron metabolism in Pseudomonas: salicylic acid, a siderophore of Pseudomonas fluorescens CHA0. BioFactors 4:23-27.

Raupach, G. S., Liu, L., Murphy, J. F., Tuzun, S., and Kloepper, J. W. 1996. Induced systemic resistance in cucumber and tomato against cucumber mosaic cucumovirus using plant growth-promoting rhizobacteria (PGPR). Plant Dis. 80:891-894.

Sayler, R. J., Wei, G., Kloepper, J. W., and Tuzun, S. 1994. Induction of $\beta$-1,3-glucanases and chitinases in tobacco by seed treatment with select strains of plant growth promoting rhizobacteria. (Abstr.) Phytopathology 84:1107-1108.

Schwyn, B., and Neilands, J. B. 1987. Universal chemical assay for the detection and determination of siderophores. Anal. Biochem. 160:4756.

Serino, L., Reimmann, C., Baur, H., Beyeler, M., Visca, P., and Haas, D. 1995. Structural genes from salicylate biosynthesis from chorismate in Pseudomonas aeruginosa. Mol. Gen. Genet. 249:217-228.

Shulaev, V., León, J., and Raskin, I. 1995. Is salicylic acid a translocated signal of systemic acquired resistance in tobacco? Plant Cell 7:16911701.

Thompson, D. C., and Jenkins, S. F. 1985. Pictorial assessment key to determine fungicide concentrations that control anthracnose development on cucumber cultivars with varying resistance levels. Plant Dis. 69:833-836.

Uknes, S., Mauch-Mani, B., Moyer, M., Williams, S., Dincher, S., Chandler, D., Potter, S., Slusarenko, A., Ward, E., and Ryals, J. 1992. Acquired resistance in Arabidopsis. Plant Cell 4:645-656.

van Peer, R., Niemann, G. J., and Schippers, B. 1991. Induced resistance and phytoalexin accumulation in biological control of Fusarium wilt 
of carnation by Pseudomonas sp. strain WCS417r. Phytopathology 81:728-734.

Visca, P., Ciervo, A., Sanfilippo, V., and Orsi, N. 1993. Iron-regulated salicylate synthesis by Pseudomonas spp. J. Gen. Microbiol. 139: 1995-2001.

Ward, E. R., Uknes, S. J., Williams, S. C., Dincher, S. S., Wiederhold, D. L., Alexander, D. C., Ahl-Goy, P., Métraux, J.-P., and Ryals, J. A. 1991. Coordinate gene activity in response to agents that induce systemic acquired resistance. Plant Cell 3:1085-1094.

Wei, G., Kloepper, J. W., and Tuzun, S. 1991. Induction of systemic resistance of cucumber to Colletotrichum orbiculare by select strains of plant growth-promoting rhizobacteria. Phytopathology 81:1508-1512.

Wei, G., Kloepper, J. W., and Tuzun, S. 1996. Induced systemic resistance to cucumber diseases and increased plant growth by plant growth-promoting rhizobacteria under field conditions. Phytopathology 86:221-224.

White, R. F. 1979. Acetylsalicylic acid (aspirin) induces resistance to tobacco mosaic virus in tobacco. Virology 99:410-412.

Yalpani, N., Silverman, P., Wilson, T. M. A., Kleier, D. A., and Raskin, I. 1991. Salicylic acid is a systemic signal and an inducer of pathogenesisrelated proteins in virus-infected tobacco. Plant Cell 3:809-818.

Yao, C., Wei, G., Zehnder, G. W., Shelby, R. A., and Kloepper, J. W. 1994. Induced systemic resistance against bacterial wilt of cucumber by select plant growth-promoting rhizobacteria. Phytopathology (Abstr.) 84:1082.

Yen, K-M., and Serdar, C. M. 1988. Genetics of naphthalene catabolism in Pseudomonads. CRC Crit. Rev. Microbiol. 15:247-268.

Zdor, R. E., and Anderson, A. J. 1992. Influence of root colonizing bacteria on the defense responses of bean. Plant Soil 140:99-107. 